\title{
Teaching About International Families Across the United States
}

\author{
Mihaela Robila \\ Alan C. Taylor
}

\begin{abstract}
Due to increasing globalization, teaching students about international families is important in preparing them to become competent multicultural educators. This study assessed the current existence of family studies courses across the United States which focus on international families. More than 110 undergraduate and 76 graduate family science/studies programs were reviewed. However, only 20 undergraduate and 10 graduate courses on international families or cross-cultural perspectives on families were identified. Recommendations are provided for including this type of course in family studies curricula, and several textbooks on international families are suggested. [Article copies available for a fee from The Haworth Document Delivery Service: 1-800-HAWORTH. E-mail address: <docdelivery@haworthpress.com> Website: <http://www.HaworthPress.com> () 2005 by The Haworth Press, Inc. All rights reserved.]
\end{abstract}

KEYWORDS. Family studies courses, international families, teaching

Mihaela Robila is affiliated with Queens College, City University of New York. Alan C. Taylor is affiliated with Syracuse University.

Address correspondence to: Mihaela Robila, PhD, CFLE, Assistant Professor in Family Science, 306 Remsen Hall, Queens College, CUNY, 65-30 Kissena Boulevard, Flushing, NY 11367 (E-mail: mrobila@qc.edu).

Available online at http://www.haworthpress.com/web/MFR (c) 2005 by The Haworth Press, Inc. All rights reserved. doi:10.1300/J002v38n03_03 


\section{INTRODUCTION}

Culture influences all aspects of human life, including values, assumptions, beliefs, and practices (Arnett, 2002). The influence of culture becomes much more complex in an interdependent and interconnected world where modern technology, travel, human migration, multinational economic developments, and other globalization trends have blurred borders between cultures (Fountin, 1995; Lim \& Renshaw, 2001). The increasing interconnectedness and intermingling of cultures as a result of globalization requires that pedagogies concerning diversity focus on creating new knowledge and meanings about changing cultures (Banks, 2001; Germain, 1998; Lim \& Renshaw, 2001). While students who travel or study abroad may experience first hand other cultures and families, those without such opportunities often fail to acquire new knowledge and gain meaningful experiences with diverse cultures. For students without these experiences, it is mandatory that they be provided with a curriculum that offers courses on cultural diversity and/or international issues.

The adjustment of the educational system to the needs of current society is imperative. Research has assessed the role of multicultural education in preparing students to face the challenges of the world (Roopnarine \& Gielen, 2004). How universities approach multicultural education and integrate it into their curricula is an indicator of the value placed on its importance. Gay and Fox (1995) describe four themes regarding the theory and philosophy of multicultural education: (1) the importance of contextual and developmental appropriateness in making decisions about educational reforms to promote ethnic and cultural diversity (relationship between formal institutional policies and practices, informal expectations); (2) the implementation of multicultural education requires systematic and systemic change (purposeful planning, regularity of occurrence); (3) the integral role of personal values, beliefs, and life experiences in teaching and learning processes; and, (4) multicultural education is transformative and revolutionary (advocates cooperative plurality).

It is desirable for multicultural education to be included in all departments, and not limited solely to anthropology or cultural studies programs (Arnett, 2002; Comunian \& Gielen, 2001). The increasing complexity of family matters (e.g., structure) in recent decades has contributed to the growth of family studies as a field and the increase in family studies programs throughout the country. 
Given the rapid rate of globalization, teaching about international families by using a cross-cultural approach becomes increasingly important (Roopnarine \& Gielen, 2004). Understanding complex family issues from an international perspective prepares students to work more effectively with scholars and families from other cultures. By establishing May 13th as the Day of International Families and celebrating the 10th Anniversary of the Year of the Family in 2004, the United Nations recognized the importance of understanding families in a multicultural world. By learning how families are affected by social, economic, and political forces, scholars can better identify ways to help families adapt and live fulfilling lives.

As part of the global community, organizations in the United States have played an active role in promoting the well being of international families by creating and supporting family programs, and by organizing conferences and seminars on family issues (i.e., National Council on Family Relations, International Family Strengths Conferences). Such activities demand professionals well-trained in cultural diversity and family functioning in different societies. Universities and family studies programs need to produce more scholars who are prepared to fulfill these roles. More specifically, the way programs organize their curricula to include courses such as Teaching about International Families become critical factors in the students' educational experience and professional development.

As in other fields, family studies has to reflect the needs of the modern world. Further, as people travel more frequently and become involved in various international programs, understanding more about the world's families becomes an important tool of diplomacy. Educating family studies students about global issues helps produce competent professionals ready to tackle the current issues of society. Courses on teaching about international families as well as teaching about ethnic diversity should be part of a program's core requirements to ensure the exposure of all students to issues of cultural diversity. There is a need for family studies programs to introduce students to other cultures, while attempting to instill feelings of acceptance, and tolerance of differences, as there is little doubt they will be exposed to people of all types and nationalities in the workforce.

Although there is some literature on multicultural education (e.g., Bennett, 2003; Gollnick, 2002; Lantis \& Kuzma, 2000; Pang, 2001), the research on teaching about international families appears to be extremely limited. The goal of this article is twofold: One, to examine the current status of family studies courses at universities in the United 
States that focus on international families. And two, to identify and highlight textbooks that might prove useful in teaching about international families.

\section{METHODS}

\section{Procedure}

In conducting our review of programs we began with the "Graduate and Undergraduate Study in Marriage and Family: A guide to Bachelor's, Master's, and Doctoral Programs in the United States and Canada" edited by Jason D. Hans (2002). While the guide contains information about 235 family programs in the United States and Canada, this study focuses only on programs in the United States. The publication includes reviews of various departments, including family studies, family therapy, family and consumer sciences, psychology, counseling, and sociology. The author of the guide contacts university administrators and requested specific information about their programs including the courses they offer (Hans, 2002). Updated every three years, it represents perhaps the most comprehensive listing of undergraduate and graduate programs in the field of family studies.

The next step was to identify course titles in family studies/science programs that indicated international/cross-cultural content specifically. Courses focused on "international families" include such terms as marital relations, gender roles, and parenting in families in other countries. We defined the term "cross-culturalism" to be synonymous with the idea of going across cultures, which is not the same as courses focusing on the variation/diversity within a certain culture. Therefore, for recording purposes, courses with "international/cross-culturalism" within their titles were grouped separately from those focusing on the diversity within a specific culture (e.g., courses on ethnicity, race, or gender).

After reviewing a list of study areas provided by departments of universities, those identified as family science/studies were selected (Hans, 2002). Examples included, "Child and Family Studies," Child and Family Development," "Family and Consumer Sciences," "Family and Community," "Family Development," "Family and Human Services," "Family Studies," "Human Development and Family Studies," and "Family Life Education." The study included 110 undergraduate and 76 graduate programs. 


\section{Data Analysis}

The comparative method of analysis (Miles \& Huberman, 1994; Strauss \& Corbin, 1990) was used to examine the data. The courses were compared for similarities and differences and both major categories and subcategories were created (Strauss \& Corbin, 1990). The two main categories created were international families and cross cultural perspectives on families (courses that focused on international families), and cultural diversity (courses that focused on general diversity within United States or on specific ethnic groups). Descriptions and syllabi of courses that covered international families were examined for their content.

\section{RESULTS}

\section{Undergraduate Courses}

Using the criteria described above, 111 undergraduate programs were identified as offering courses on international families and cultural diversity. Of those, 54 (48\%) programs offer some type of cultural diversity course. Because some programs offer more than one course on cultural diversity, a total of 74 courses on related topics were identified. Of these 74, two types of courses were identified: the first focused on cross-cultural/global context/international issues and families. The second centered on ethnic identity/race/diversity. Only 20 courses (18\%) were offered specifically on cross-cultural/international issues, with a mere six course titles reflecting some global/international content (see Table 1).

Few courses were offered specifically on the topic of international/cross-cultural/global perspectives and families. Another category included courses on diversity. In some cases, the courses focused directly on "cultural diversity," while others addressed "diversity" more indirectly. By offering courses specifically on international families, students are given the opportunity to gain more in-depth knowledge about families in different cultural settings. It also helps to create awareness among students that not all families have similar experiences, which is essential to developing cultural sensitivity. Within the diversity/ethnicity category, some courses focused on race and ethnicity/minorities in general, while others focused on a single ethnic group, such as African American or Latino. There was no course offered on Asian 
TABLE 1. Undergraduate Courses Offered on Cultural Diversity

\begin{tabular}{|c|c|c|c|}
\hline Category & Sub-Category & $\begin{array}{l}\text { Number } \\
\text { of } \\
\text { Courses }\end{array}$ & Examples of Undergraduate Courses \\
\hline \multirow{3}{*}{$\begin{array}{l}\text { International } \\
\text { Families/Cross- } \\
\text { Cultural } \\
\text { Perspectives } \\
\text { on Families }\end{array}$} & $\begin{array}{l}\text { International } \\
\text { Families and } \\
\text { Children }\end{array}$ & 4 & $\begin{array}{l}\text { "The Family in International Settings" } \\
\text { "International Approaches to Child Advocacy" } \\
\text { "International Families" }\end{array}$ \\
\hline & $\begin{array}{l}\text { Cross-Cultural } \\
\text { Perspectives on } \\
\text { Families }\end{array}$ & 14 & $\begin{array}{l}\text { "The Child and Family in Cross-Cultural } \\
\text { Perspective" } \\
\text { "Family in Cross-Cultural Perspectives" } \\
\text { "Cross-Cultural Family Patterns" } \\
\text { "Family Diversity Across Cultures" } \\
\text { "Family Life Education Across Cultures" }\end{array}$ \\
\hline & $\begin{array}{l}\text { Global Context/ } \\
\text { Multicultural }\end{array}$ & 6 & $\begin{array}{l}\text { "Marriage and Family in a Global Context" } \\
\text { "Global and Diverse Families" } \\
\text { "Multicultural Families" } \\
\text { "Family Stress and Coping: Multicultural } \\
\text { Focus" }\end{array}$ \\
\hline \multirow{4}{*}{$\begin{array}{l}\text { Cultural Diversity/ } \\
\text { Diversity Within } \\
\text { United States }\end{array}$} & Diversity & 19 & $\begin{array}{l}\text { "Family Diversity" } \\
\text { "Families and Cultural Diversity" }\end{array}$ \\
\hline & Ethnicity/Race & 19 & $\begin{array}{l}\text { "Human Services and Family Ethnicity" } \\
\text { "Ethnic Identity and Awareness in Children } \\
\text { and Families" }\end{array}$ \\
\hline & $\begin{array}{l}\text { Black/African } \\
\text { American }\end{array}$ & 9 & $\begin{array}{l}\text { "Black American Family Patterns" } \\
\text { "Black Families" }\end{array}$ \\
\hline & Latinos & 3 & $\begin{array}{l}\text { "Latina/Latino Families and Children in the } \\
\text { United States" } \\
\text { "Latinos" }\end{array}$ \\
\hline
\end{tabular}

American families. A third category included courses that address family diversity within the United States.

\section{Graduate Courses}

Seventy-six graduate programs, identified by the criteria described above, offered courses on international families. As presented in Table 2, 29 programs (38\%) offered 39 courses on cultural diversity. Of the 29 graduate programs, $18(62 \%)$ also offered courses on cultural diversity at the undergraduate level. Only five course titles were found to focus exclusively on international families. Examples of the courses offered are provided in Table 2 . 
TABLE 2. Graduate Courses Offered on Cultural Diversity

\begin{tabular}{|c|c|c|c|}
\hline Category & Sub-Category & $\begin{array}{l}\text { Number } \\
\text { of } \\
\text { Courses }\end{array}$ & Examples of Courses \\
\hline \multirow{2}{*}{$\begin{array}{l}\text { International } \\
\text { Families/Cross- } \\
\text { Cultural } \\
\text { Perspectives on } \\
\text { Families }\end{array}$} & $\begin{array}{l}\text { International } \\
\text { Families }\end{array}$ & 5 & $\begin{array}{l}\text { "International Home Economics" } \\
\text { "History of Family in Russia" } \\
\text { "International Approaches to Child Advocacy" }\end{array}$ \\
\hline & $\begin{array}{l}\text { Cross-Cultural } \\
\text { Perspectives }\end{array}$ & 5 & $\begin{array}{l}\text { "Cross-Cultural Perspectives" } \\
\text { "Childhood and Family in Cross-Cultural } \\
\text { Perspectives" } \\
\text { "Human Development in Cross-Cultural } \\
\text { Perspectives" }\end{array}$ \\
\hline \multirow[t]{4}{*}{$\begin{array}{l}\text { Cultural Diversity/ } \\
\text { Diversity Within } \\
\text { United States }\end{array}$} & Diversity & 10 & $\begin{array}{l}\text { "Cultural Influences on Children and } \\
\text { Families" } \\
\text { "Culturally Diverse Family Systems" } \\
\text { "Diversity in Individuals and Families" }\end{array}$ \\
\hline & Ethnicity & 1 & $\begin{array}{l}\text { "Advanced Seminar in Multi-Cultural } \\
\text { Families" }\end{array}$ \\
\hline & General & 15 & $\begin{array}{l}\text { "Ethnic Families" } \\
\text { "Gender and Minorities Across the Lifespan" } \\
\text { "Gender and Ethnicity" }\end{array}$ \\
\hline & $\begin{array}{l}\text { Black/African } \\
\text { American }\end{array}$ & 3 & $\begin{array}{l}\text { "The Afro-American Family" } \\
\text { "Development of Black Children and Their } \\
\text { Families: Research and Policy" }\end{array}$ \\
\hline
\end{tabular}

A review of the descriptions and syllabi for undergraduate and graduate courses on international families revealed several common themes; these syllabi were obtained based on internet searches using keywords similar to the ones used to identify the original courses. All the courses aimed to provide an overview of family dynamics in different cultures. Among the processes explored were marital functioning, gender roles, and child rearing beliefs and strategies. The courses were also designed to give students the opportunity to appreciate the roles of political, socio-economic, and cultural influences in human and family development. With respect to course objectives, students are expected to acquire a broad understanding of culture, understand specific theories on human and family development, explore contemporary methodologies used in the study of families across cultures, analyze the link between family processes and family outcomes in different cultures, and discuss policies employed by different societies which affect families and children. 


\section{DISCUSSION}

The results of the study indicate that the number of courses offered on cultural diversity is relatively small, with more than half of the undergraduate programs not offering a single class on diversity. Surprisingly, the number of graduate courses on cultural diversity is even smaller, with less than $40 \%$ of the departments offering courses on cultural diversity. Furthermore, very few graduate programs offer courses on international families. This could be the result of the lack of textbooks on international families until recently which hindered the development of courses on families in different countries.

\section{Strengths and Limitations}

This study has several unique and important strengths. First, it is perhaps the first study that explored course offerings on cultural diversity in graduate and undergraduate family studies programs. Second, by reviewing programs in several areas related to family sciences (such as family studies, family services, family life education) a considerable assortment of programs was identified. And third, studying a representative sample of many colleges and university programs around the nation provided a more comprehensive look at the current situation in the family studies field.

When discussing the results of this study, certain limitations have to be considered. The "Guide of Graduate and Undergraduate Programs in Marriage and Family" contains information on a limited number of programs. There may be programs in existence that offer courses on cross-culturalism/international families and related topics that are not included in the guide Also, not having syllabi for all of the courses identified made it difficult to evaluate their content; given the extension of Blackboard (and similar tools) it is increasingly likely that syllabi will no longer be available online. In addition, some courses on international families might have been missed under the unspecified umbrella of "advanced topics" or "seminars." However, listing a course under this category suggests that the course, although offered, is not offered regularly. It is recommended that as the number of courses of this type increases, the textbooks, activities, learning materials, and teaching techniques be evaluated. 


\section{Recommendations}

Curriculum changes are necessary if we want to promote multicultural education in family studies departments. Many of the programs reviewed prepare future teachers and are therefore influential with respect to long-term educational practices. Often, graduating students in these programs enter K-12 classrooms and other educational settings as teachers, promoting, or sometimes not promoting, cultural diversity awareness (Gay \& Fox, 1995). Graduates entering the workforce who have had the opportunity to take courses centered on multicultural education will be better equipped with the skills and knowledge to interact with and understand the dynamics of immigrant families residing in the U.S. For example, social service professionals assigned to an immigrant family will be a step ahead if they are aware of the cultural specifics of that family. Also, family life educators teaching community parenting and marriage education classes will be more sensitive to the dynamics of other cultures if they have been taught about diversity in their university courses.

The offering of introductory courses as well as more advanced or more specialized courses (e.g., focused on parenting or policies in different countries) would be beneficial. There is an urgent need to introduce this type of course in the curricula, particularly at the graduate level. Graduates of masters and doctoral programs in family studies have considerable opportunities and a profound responsibility to be knowledgeable proponents of cultural diversity.

We recommend including courses on cultural diversity, not only as optional electives, but also as core course requirements for family science programs. In addition, we recommend emphasizing the study of international families as a part of the requirements under the first content area-family diversity-for the Certification of Family Life Educators (CFLE) sponsored by the National Council on Family Relations (NCFR) (Bredehoft \& Cassidy, 1995). If the NCFR CFLE program were to emphasize the benefits of courses on international families, it might motivate family studies programs to include these types of courses in their curriculum.

Offering courses on cultural diversity is not enough to ensure a thorough cultural education, however. Multicultural competence is emerging as a defining feature in professional development, training, and education (Sue, Bingham, \& Vasquez, 1999). Thus, courses should include meaningful instructional methods, such as a focus on affective learning, personal involvement, and giving voice to multiple social real- 
ities (Gay \& Fox, 1995). It is not enough that students learn about families in different cultures; they must also understand the personal and social value of this knowledge (Banks, 1994; Gay \& Fox, 1995). Teaching strategies should legitimize the voices and experiences of different ethnic and cultural groups, and provide students with opportunities to examine their feelings about issues of cultural diversity (Gay \& Fox, 1995). Courses on international families should also teach students to be reflective, critical thinkers, and decision makers, and to promote social justice (Darling-Hammond, French, \& Garcia-Lopez, 2002; Gay, 1994; Van Soest \& Garcia, 2003). The courses which are currently being offered may already utilize these pedagogies; this would be an area of study for future research.

As family scholars and teachers strive to educate and influence others through community programming (e.g., parenting classes), there is a growing need for professionals to understand and show sensitivity to the cultural context of the population they teach. As the U.S. population continues to become increasingly diverse, family scholars will likely encounter many people from distinctive ethnic and cultural backgrounds (Dilg, 1999; Forehand \& Kotchick, 1996; Kailin, 2002). Courses on multicultural diversity should address the unique cultural contributions and potential barriers to effective family programs (e.g., parent training) future family educators may encounter. It is only through an awareness of, and an appreciation for, the diversity of cultures that family scholars will achieve their goal of helping families live life to its fullest potential within the context of their particular culture, as well as within the umbrella culture of society at large (Forehand \& Kotchick, 1996).

\section{TEXTBOOKS FOR TEACHING ABOUT INTERNATIONAL FAMILIES}

A challenge for any course instructor is finding appropriate textbooks to meet the demands of the desired course objectives. An additional goal of this paper was to identify a handful of appropriate textbooks that may be employed in courses studying international families and relationships. To examine current family relationships and human development from around the world, we have identified textbooks that seem to provide appropriate research and content from a true international perspective. 
Elaine Leeder's (2004) book, The Family in Global Perspective: A Gendered Journey, examines the continually changing faces of family life in western countries and contrasts them with the lives of families in parts of Africa, Asia and Latin America. By first comparing the history of the family from various parts of the globe, Leeder looks at the impact of globalization on family structure; gendered behavior; intergenerational relationships; and relationship dissolution.

Jaipaul Roopnarine and Uwe Gielen (2004) edited Families in Global Perspective, which examines 14 different cultures from around the globe and their respective family dynamics. Some of the cultures examined include China, Indonesia, Egypt, Turkey, Brazil and South Africa. The authors address multiple family topics from these cultures, including such areas as gender socialization, parent-child relationships, marriage and mating, and division of household labor, among others.

In Lives Across Cultures: Cross Cultural Human Development (Gardiner, Mutter, \& Kosmitzki, 1998), basic principles and research findings are connected to practical everyday situations that take place in diverse cultures throughout the world. The authors present global research in the area of social settings (family, school and culture) and the activities occurring within them (social interactions, personality development, and cognitive change). As opposed to covering families from different international communities, each chapter focuses on social settings and activities and then discusses the international research surrounding them.

Robila's (2004) edited book, Families in Eastern Europe, examines family patterns and changes in 14 countries in Eastern Europe (e.g., Bulgaria, Czech Republic, Hungary, Lithuania, Macedonia, Poland, Romania, Russia). The authors of each chapter explain family processes in each particular country, focusing on the historic, social and economic contexts and the impact they have on families. The book provides demographic information about families and discusses cultural traditions, marital and gender roles, parenting processes, family policy and a sampling of programs within each society.

International Perspectives on Family Violence and Abuse: A Cognitive Ecological Approach, an edited book by Malley-Morrison (2004), addresses the question of domestic violence and its culturally specific definitions in various areas around the world. Chapters include cultural and historical experiences that contribute to differences and similarities in the perspectives on family violence held by citizens of different countries. 
Hamon and Ingoldsby's (2003) Mate Selection Across Cultures provides a contemporary, global perspective on the couple formation process in various regions of the world, including Ecuador, Kenya, Israel, Spain, and others. The chapters underline the variation that exists within any one country and also reviews such concepts as modernization/traditionalism, arranged marriage/free choice, love/family practicality, cohabitation/marriage, and collectivism/individualism.

While our initial attempts to find appropriate textbooks examining international families seemed difficult, it was refreshing to discover several new textbooks recently published which will fill that void. We are hopeful that additional authors will realize the necessity of textbooks on cross-cultural topics and compile relevant current research into a textbook format, so that instructors will have many choices for a text. Finally, we believe that with the increased production of such texts, family science departments will be more apt to introduce courses on international families, cultural diversity, and related topics. Such courses are necessary in the preparation of family science specialists who will be confronting a rapidly changing world.

\section{REFERENCES}

Arnett, J. J. (2002). The psychology of globalization. American Psychologist, 57, 774-783.

Banks, J. A. (1994). An introduction to multicultural education. Boston: Allyn and Bacon. Banks, J. A. (2001). Cultural diversity and education: Foundations, curriculum and teaching. Needham Heights, MA: Pearson Education Company.

Bennett, C. (2003). Comprehensive multicultural education: Theory and practice. Boston: Allyn and Bacon.

Bredehoft, D. \& Cassidy, D. (Eds.). (1995). College and university curriculum guidelines in Family Life Education. Minnesota: National Council on Family Relations. Retrieved 6-22-05 from http://www.ncfr.org/pdf/FLE_Substance_Areas.pdf

Comunian, A. \& Gielen, U. (Eds.). (2001). International perspectives on human development. Lengerich, Germany: Pabst.

Darling-Hammond, L., French, J., \& Garcia-Lopez, M. (2002). Learning to teach for social justice. New York: Teachers College Press.

Dilg, M. (1999). Race and culture in the classroom: Teaching and learning through multicultural education. Boston: Allyn and Bacon.

Forehand, R. \& Kotchick, B. A. (1996). Cultural diversity: A wake-up call for parent training. Behavior Therapy, 27, 187-206.

Fountin, S. (1995). Education for development: A teacher's source for global learning. Portsmouth, NH: Heinemann. 
Gardiner, H. W., Mutter, J. D., \& Kosmitzki, C. (1998). Lives across cultures: Cross-cultural human development. Boston: Allyn and Bacon.

Gay, G. (1994). At the essence of learning: Multicultural education. West Lafayette, IN: Kappa Delta Phi.

Gay, G. \& Fox, W. (1995). The cultural ethos of the academy: Potentials and perils for multicultural education reform. In S. Jackson \& J. Solis (Eds.), Beyond the comfort zones in multiculturalism: Confronting the politics of privilege (pp. 239-257). Westport, CT: Bergin \& Garvey.

Germain, M. H. (1998). Worldly teachers: Cultural learning and pedagogy. Westport, CT: Bergin \& Garvey.

Gollnick, D. M. (2002). Multicultural education in a pluralistic society (6th ed.). Upper Saddle River, NJ: Merrill.

Hamon, R. R. \& Ingoldsby, B. (2003). (Eds.). Mate selection across cultures. Thousand Oaks, CA: Sage Publications.

Hans, J. D. (2002). Graduate and undergraduate study in marriage and family: A guide to bachelor's, master's, and doctoral programs in the United States and Canada. Columbia, MO: Family Scholar Publications.

Kailin, J. (2002). Antiracist education: From theory to practice. Lanham, MD: Rowman \& Littlefield Publishers.

Lantis, J. S. \& Kuzma, L. M. (2000). (Eds.). The new international studies classroom: Active teaching, active learning. Boulder, CO: Lynne Rienner Publishers.

Leeder, E. J. (2004). The family in global perspective: A gendered journey. Thousand Oaks, CA: Sage Publications.

Lim, L. \& Renshaw, P. (2001). The relevance of sociocultural theory to culturally diverse partnerships and communities. Journal of Child and Family Studies, 10, 9-21.

Malley-Morrison, K. (2004). International perspectives on family violence and abuse: A cognitive ecological approach. Mahwah, NJ: Erlbaum.

Miles, M. B. \& Huberman, M. A. (1994). Qualitative data analysis (2nd ed.). Thousand Oaks, CA: Sage Publications.

Pang, V. O. (2001). Multicultural education: A caring-centered, reflective approach. Boston: McGraw-Hill.

Robila, M. (Ed.). (2004). Families in Eastern Europe. Oxford: Elsevier.

Roopnarine, J. L. \& Gielen, U. P. (Eds.). (2004). Families in a global perspective: An introduction. Boston: Allyn and Bacon.

Strauss, A. \& Corbin, J. (1990). Basics of qualitative research. Newbury Park, CA: Sage. Publications.

Sue, D. W., Bingham, R. P., \& Vasquez, M. (1999). The diversification of psychology: A multicultural revolution. American Psychologist, 54, 1061-1069.

Van Soest, D. \& Garcia, B. (2003). Diversity education for social justice: Mastering teaching skills. Alexandria, VA: Council on Social Work Education. 